\title{
Pendidikan Karakter Melalui Metode Pembiasaan di SDIt al Kindikota PeKanbaru Kecamatan Tenayan Raya
}

\author{
Ady Putra Siregar \\ Program Studi Magister Manajemen Pendidikan Islam Pascasarjana Universitas Islam Bandung
}

\begin{abstract}
SDIT Al Kindi Pekanbaru is one of the schools that successfully implemented character building through habituation method. Based on the background, this study aims to examine the planning, implementation, and assessment of character building through the habituation method in SDIT Al Kindi Pekanbaru City and examine the supporting and inhibiting factors. The research method used is descriptive method with qualitative approach. Data collection is conducted through interview, observation and documentation. The research result showed that, the plannimg process of character building program is started before the new school year through the official meeting attended by the vice principals and all the teachers and administrative staff to formulate and arrange the program, determine the habituation guidance to for teachers to follow in the field. The formulation of the curriculum is integrated with the method of habituation which is composed based on the content of the Qur'an and Sunnah of Prophet Muhammad SAW and daily manners based on Islamic teaching. In the implementation process, character building through the habituation method in SDIT AL-Kindi has been integrated with daily activities in school, integrated with all subjects and also integrated with spontaneous daily activities of students both at school and outside school. SDIT Al Kindi compiled a daily activities agenda that contain the activities of habituating students practicing worship and practicing the Sunnah of the Prophet Muhammad. In the evaluation phase, SDIT Al Kindi School conducts evaluation periodically through assessment of student attitude and behaviour pattern and evaluated from success indicators of habituation program such as guest satisfaction, parental satisfaction, report of homeroom and wakasis, teacher report of study area, on local communities report and a surge in new students' acceptance. Supporting factor of habituating program success is the parity of vision and mission of the school and parents, as well as the parents support in the implementation of character education. While the inhibiting factors are the limited human resources, limited funds and the uncontrollable students's environment outside school.
\end{abstract}

Keywords : The Management Of Character Education Through The Costum Method.

\footnotetext{
Abstrak. SDIT Al Kindi Kota Pekanbaru merupakan salah satu sekolah yang berhasil menerapkan pendidikan karakter melalui metode pembiasaan. Berdasarkan latar belakang tersebut penelitian ini bertujuan untuk mengetahui perencanaan, pelaksanaan, dan penilaian pendidikan karakter melalui metode pembiasaan di SDIT Al Kindi Kota Pekanbaru serta mengetahui faktor-faktor pendukung dan penghambatnya. Metode penelitian yang digunakan adalah metode deskriptif dengan pendekatan kualitatif. Pengumpulan data dilakukan melalui wawancara, observasi serta dokumentasi. Berdasarkan hasil penelitian diketahui bahwa pada proses perencanaan program pendidikan karakter dimulai dilaksanakan sebelum tahun ajaran baru melalui rapat dinas yang dihadiri para wakil kepala sekolah dan semua guru serta staf tata usaha untuk merumuskan dan menyusun program, menentukan panduan pembiasaan untuk menjadi pedoman para guru di lapangan. Perumusan kurikulum diintegrasikan dengan metode pembiasaan yang disusun berdasarkan kandungan Al Qur'an dan Sunnah Rosulullah serta adab sehari-hari dalam Islam. Pada proses pelaksanaan,
} 
pendidikan karakter melalui metode pembiasaan di SDIT Al Kindi telah terintegrasi dengan kegiatan sehari-hari di sekolah, terintegrasi dengan semua mata pelajaran dan juga terintegrasi dengan kegiatan spontan siswa sehari-hari baik di sekolah maupun di luar sekolah. SDIT Al Kindi menyusun agenda kegiatan sehari-hari yang berisi kegiatan pembiasaan siswa menjalankan ibadah dan menjalankan Sunnah Nabi Muhammad. Pada tahap evaluasi, Sekolah SDIT Al Kindi melakukan evaluasi secara berkala melalui penilaian terhadap pola sikap siswa dan ditinjau dari indikator-indikator keberhasilan program pembiasaan indikator tersebut antara lain kepuasan tamu, kepuasan orang tua, laporan wali kelas dan wakasis, laporan guru bidang studi, laporan masyarakat setempat dan lonjakan penerimaan peserta didik baru.Faktor-faktor pendukung keberhasilan antara lain kesamaan visi dan misi sekolah dengan orang tua, serta dukungan orang tua dalam pelaksanaan pendidikan karakter. Sedangkan faktor penghambat adalah keterbatasan sumber daya manusia, keterbatasan dana serta pergaulan siswa di lingkungan luar sekolah yang sulit terkontrol.

Kata Kunci : Manajemen Pendidikan Karakter Melalui Metode Pembiasaan.

\section{Pendahuluan}

Akhlak generasi bangsa semakin lama semakin memprihatinkan. Fenomena melorotnya akhlak generasi bangsa, termasuk di dalamnya para elit bangsa, acapkali menjadi apologi bagi sebagian orang untuk memberikan kritik pedasnya terhadap institusi pendidikan. Kesalahan ini menyebabkan keterpurukan kondisi bangsa Indonesia yang dirasakan dewasa ini, penyebab utamanya karena keimanan, ketaqwaan dan akhlak mulia umumnya belum tertanam dalam jiwa bangsa Indonesia. Keberhasilan suatu bangsa dalam memperoleh tujuannya tidak hanya ditentukan oleh melimpah ruahnya sumber daya alam, tetapi sangat ditentukan oleh kualitas sumber daya manusianya, bahkan ada yang mengatakan bahwa bangsa yang besar dapat dilihat dari kualiatas/karakter bangsa (manusia) itu sendiri.

Salah satu cara pemerintah untuk menghadang fenomena tersebut, pemerintah menggulirkan program pendidikan karakter pada semua instansi terutama instansi pendidikan, sehingga Indonesia mempunyai moral yang baik.

Pendidikan karakter merupakankonsep pemerintah dalam mengatasi derasnya arus globalisasi yang dibarengi dengan semakin meningkatnya perkembangan teknologi. Pendidikan karakter diharapkan dapat membekali anak didik yang notabane generasi penerus bangsa akhlak yang baik, sopan, juga budi pekerti luhur sejak dari kecil sehingga jika mereka nanti memasuki dunia kerja, mereka menjadi sumber daya manusia yang taat kepada Tuhan Yang Maha Esa, sopan terhadap sesama dan mempunyai jiwa mandiri serta bertanggung jawab dengan pekerjaannya.

Pendidikan karakter

mengajarkan kepada anak tentang cara berfikir dan berperilaku yang dapat membantu individu untuk hidup dan bekerja bersama sebagai keluarga, masyarakat dan negara serta membentuk mereka untuk dapat membuat keputusan yang dapat dipertanggung jawabkan. Hill dalam (Muslich, 2005: 38).

Quraish Syihab mengungkapkan: "keberhasilan pendidikan karakter ditentukan oleh integrasi antara olah jiwa, adanya pembiasaan, keteladanan, dan lingkungan yang sehat". Hal demikian menginterpretasikan bahwasanya pendidikan karakter tidah hanya berproyeksi pada aspek kognitif, akan 
tetapi menyeluruh maupun mendalamnya penanaman nilai dan sikap merupakan hal yang sangat urgen bagi keberhasilan pendidikan karakter yang diharapkan.

Dengan kata lain, pembiasaan yang dilakukan sejak dini akan berdampak besar terhadap akhlak anak ketika mereka telah dewasa. Sebab pembiasaan yang telah dilaksanakan sejak kecil akan melekat kuat di ingatan dan menjadi kebiasaan yang tidak dapat dirubah dengan mudah. Dengan demikian metode pembiasaan sangat baik dalam rangka mendidik akhlak anak.

Pembiasaan adalah upaya praktis dalam pendidikan dan pembinaan anak. Hasil dari pembiasaan yang dilakukan seorang pendidik adalah terciptanya suatu kebiasaan bagi anak didiknya. Kebiasaan itu adalah suatu tingkah laku tertentu yang sifatnya otomatis, tanpa direncanakan dulu, serta berlaku begitu saja tanpa dipikir lagi. (Suardi, 2011: 123). Metode pembiasaan keagamaan di sekolah dilakukan adalah menciptakan suasana religius di sekolah, karena kegiatankegiatan keagamaan dan praktikpraktik keagamaan dapat mentransformasikan dan menginternalisasikan nilai-nilai ajaran Islam serta dapat menguatkan nilai karakter budi pekerti luhur baik kepada peserta didik.

Proses untuk membiasakan diri dalam pembelajaran di sekolah memiliki arti penting dalam sebuah proses pendidikan dan kebiasaan menjadi kunci kesuksesan seseorang dalam mendidik. Untuk itu dalam sebuah keunggulan belajar bukanlah pada perbuatan semata melainkan sebuah kebiasaan, dan dalam mengawali sebuah kebiasaan yang positif dan berarti bagi peserta didik yang dianggap efektif dan responsif itu melalui pembiasaan yang baik (uswah).
Keteladan dalam pendidikan merupakan metode yang berpengaruh dan terbukti berhasil dalam mempersiapkan dan membentuk aspek moral, spiritualitas dan etos sosial anak. SDIT Al Kindi Kota Pekanbaru, merupakan salah satu sekolah yang menekankan pentingnya pembinaan karakter bagi siswa. Sekolah ini tidak hanya bertanggung jawab agar anak didiknya menjadi lulusan yang tidak hanya cakap dari sisi kemampuan kognitif, tetapi juga memiliki keshalehan yang baik atau akhlak mulia yang tinggi.

Berdasarkan observasi awal terdapat 10 ahlak yang ditanamkan kepada siswa antara lain Salimul Aqidah atau aqidah yang bersih dengan mengikuti ketentuan-ketentuan agama untuk mendekatkan diri kepada Allah, Shohilul Ibadah atau taat beribadah sesuai ketentuan agama dan Sunah Rasul, Matinul Khuluq yaitu ahlak yang baik dalam hubungannya dengan Allah SWT maupun dengan sesama mahluk hidup ciptan Allah lainnya, Qadirin Alal Qasby yaitu mempertahankan kebenaran dan berjuang menegakannya, Masqoful Fikri yaitu kecerdasan dalam berfikir, Qowiyul Jism yaitu kekuatan atau kesehatan jasmani, Mujahidullinafsihi kemampuan melawan hawa nafsu, Munazhzhom Fi Syu'unihi atau kedisiplinan dan komitmen dalam menyelesaikan suatu urusan, Hasirun ala yaitu pandai memanfaatkan waktu dan Nafi'un Lighoirihi yaitu bermanfaat bagi orang lain.

Untuk mewujudkan 10 karakter tersebut, SDIT Al Kindi Kota Pekanbaru melakukan berbagai upaya. Salah satu upaya yang dilakukan adalah proses perekrutan guru yang selektif ini bertujuan untuk mendapatkan guruguru terbaik yang tidak hanya memiliki kemampuan kognitif memadai melainkan juga wajib memiliki apektif 
yang tinggi sebagai model dan contoh langsung bagi peserta didik.

Dari wawancara pertama yang peneliti lakukan kepada Kepala Sekolah SDIT Al Kindi peneliti mendapati beberapa hal yang menarik dan tampak berbeda dibandingkan sekolah-sekolah pada umumnya. Hal ini terlihat dari kebiasaan siswa dan guru dalam menerapkan berbagai amalan sunnah yang diajarkan Nabi Muhammad Shalallahu 'Alaihi Wasallam. Peserta didik SDIT Al Kindi terbiasa menjalankan ibadah tepat waktu sesuai ketentuan-ketentuan agama Islam, memberikan respon secara spontan ketika melihat lingkungannya melakukan pelanggaran syar'I seperti makan dan minum berdiri, tidak menggunakan peci, menggunakan kerudung gipsi, merokok, serta berani menegur orang tuanya ketika tidak melaksanakan sholat di masjid hal ini diketahui dengan adanya kerja sama antara pihak sekolah dan orang tua selama peserta didik berada dirumah.

Dalam pembentukan karakter sekolah berupaya untuk menjadikan Nabi Muhammad Shalallahu 'Alaihi Wasallam sebagai contoh kongkrit untuk pembentukan karakter anak dengan cara mengenal secara detail sosok Nabi Muhammad Shalallahu 'Alaihi Wasallam dan mengamalkan sunnah-sunnah-Nya. Hal ini sesuai dengan yang dicanangkan Kementrian Agama, melalui Direktorat Jendral Pendidikan Islam bahwasanya Nabi Muhammad Shalallahu 'Alaihi Wasallam sebagai tokoh agung yang paling berkarakter. Empat karakter yang paling terkenal dari Nabi Muhammad Shalallahu 'Alaihi Wasallam itu adalah Shiddiq, Amanah, Tabligh, dan Fatanah.

Keberhasilan

karakter melalui metode pembiasaan sangat ditentukan oleh manajemen pendidikan karakter. Pendidikan karakter yang diterapkan oleh SDIT Al
Kindi Kota Pekanbaru Riau melalui metode pembiasaan telah membentuk karakter yang baik pada diri setiap siswa. Berdasarkan latar belakang di atas, maka melalui penelitian ini penulis bermaksud meneliti sejauh mana SDIT Al Kindi Kota Pekanbaru Riau melaksanakan komponen keberhasilan pendidikan karakter tersebut dengan segala kelebihan dan kekurangannya sehingga menghasilkan peserta didik yang berkualitas, dengan mengangkat judul Manajemen Pendidikan Karakter Melalui Metode Pembiasaan Di Sdit Al Kindi Kota Pekanbaru Kecamatan Tenayan Raya.

\section{Temuan Dan Pembahasan}

Pada proses perencanaan, tahapan awal yang dilakukan oleh SDIT Al Kindi Kota Pekanbaru adalah mengadakan rapat dinas yang dilaksanakan sebelum tahun ajaran baru berjalan dihadiri oleh para wakil kepala sekolah dan semua guru serta staf tata usaha untuk merumuskan dan menyusun program, menentukan panduan pembiasaan untuk menjadi pedoman para guru di lapangan.

Pada proses perencanaan tersebut SDIT Al Kindi Kota Pekanbaru menyusun tindakan-tindakan secara rinci yang akan dilakukan dalam melaksanakan pendidikan karakter melalui metode pembiasaan termasuk mengarahkan sumber daya secara efektif dan efisien agar tujuan dari program tersebut tercapai.

Hal tersebut sesuai dengan pengertian perencanaan yang dijelaskan oleh Sudjana (2009) bahwa perencanaan adalah proses yang sistematis dalam pengambilan keputusan tentang tindakan yang akan dilakukan pada waktu yang akan datang. Disebut sistematis karena perencanaan dilaksanakan dengan menggunakan prinsip-prinsip tertentu. Prinsip-prinsip 
tersebut mencakup proses pengambilan keputusan, penggunaan pengetahuan dan teknik secara ilmiah, serta tindakan atau kegiatan yang terorganisasi.

Selanjutnya ditetapkan bahwa tujuan yang ingin dicapai dari pendidikan karakter melalui metode pembiasaan di SDIT Al Kindi Kota Pekanbaru adalah untuk meningkatkan potensi spiritual dan membentuk perserta didik agar menjadi manusia yang memiliki keunggulan akhlak yang mulia. semua yang direncanakan, termasuk program metode pembiasaan pada pembelajaran agama dan moral harus mengarah pada pembentukan karakter.

Hal tersebut sesuai dengan tujuan pendidikan karakter yang dikemukakan oleh Koesoema (2007: 114) bahwa pendidikan karakter yang diterapkan dalam satuan pendidikan bisa menjadi salah satu sarana pembudayaan dan pemanusian. Di sinilah pendidikan sangat berperan dan pendidikan harus kembali kepada substansi utama yaitu membangun pribadi dengan karakter mulia sebagai individu, keluarga, masyarakat dan bangsa.

Pendidikan karakter ditempatkan sebagai landasan untuk mewujudkan visi pembangunan nasional, yaitu mewujudkan masyarakat berakhlak mulia, bermoral, beretika, berbudaya, dan beradab berdasarkan falsafah Pancasila.

Pada tahap selanjutnya sekolah melakukan sosialisasi pembiasaan akhlak mulia kepada para guru dan staf tata usaha serta orang tua siswa untuk menyamakan persepsi dan komitmen bersama yang kuat antara seluruh komponen warga sekolah. Sekolah selanjutnya merumuskan kurikulum pembisaan merujuk pada standar isi 10 pembiasaan yang ada. Sekolah merumuskan kurikulum yang untuk diintegrasikan dengan metode pembiasaan yang disusun isi berdasarkan kandungan Al Qur'an dan Sunnah Rosulullah serta adab seharihari dalam Islam.

10 pembiasaan tersebut dilakukan untuk membangun Muwashofat atau kriteria yang perlu ditanamkan dalam diri untuk menjaga keperibadian Muslim yang sejati yang terdiri dari Salimul Aqidah atau aqidah yang bersih dengan mengikuti ketentuan-ketentuan agama untuk mendekatkan diri kepada Allah, Shohilul Ibadah atau taat beribadah sesuai ketentuan agama dan Sunah Rasul, Matinul Khuluq yaitu ahlak yang baik dalam hubungannya dengan Allah SWT maupun dengan sesama mahluk hidup ciptan Allah lainnya, Qadirin Alal Qasby yaitu mempertahankan kebenaran dan berjuang menegakannya, Masqoful Fikri yaitu kecerdasan dalam berfikir, Qowiyul Jism yaitu kekuatan atau kesehatan jasmani, Mujahidullinafsihi kemampuan melawan hawa nafsu, Munazhzhom Fi Syu'unihi atau kedisiplinan dan komitmen dalam menyelesaikan suatu urusan, Hasirun ala yaitu pandai memanfaatkan waktu dan Nafi'un Lighoirihi yaitu bermanfaat bagi orang lain. Selain itu sekolah juga telah menetapkan indikator untuk setiap Muwashofat pada setia tinggkatan pendidikan untuk mengukur sejauh karakter-karakter tersebut telah tertanam dalam diri setiap siswa.

Dalam menjalankan program metode pembiasaan tersebut, kompetensi guru atau pendidik sangat penting. Ketersediaan sumber daya manusia yang memadai dan kompeten sangat diperlukan untuk mencapai tujuan yang ditetapkan secara maksimal. Untuk itu pada proses perencanaan sekolah menetapkan standar kompetensi bagi guru yang akan melaksanakan metode pembiasaan tersebut. 
$\begin{array}{ccr}\text { Standar } & \begin{array}{c}\text { kompetensi } \\ \text { sebagai }\end{array} & \text { tersebut } \\ \text { dilakukan } & \text { upaya }\end{array}$ mempersiapkan tenaga pengajar yang kompeten baik dalam pendidikan umum maupun pendidikan agama. Selanjutnya guru tersebut ditempatkan untuk mengajar mata pelajaran sesuai bidang keahliannya namun tetap mengintegrasikan kegiatan pengajaran dengan kegiatan pendidikan karakter melalui metode pembiasaan.

Hal tersebut sesuai dengan yang diungkapkan oleh Banghart and Trull dalam (Sa'ud, 2007: 47) bahwa apabila perencanaan disusun berdasarkan sumber daya yang tersedia secara cermat dan akurat, akan menghasilkan tingkat kelayakan rencana pendidikan yang baik.

Berdasarkan hasil penelitian diketahui bahwa pada proses perencanaan SDIT Al Kindi Kota Pekanbaru merumuskan pedoman dan aturan untuk mencapai tujuan tersebut, menetapkan standar sumber daya, menetapkan wewenang dan tanggung jawab bagi seluruh pelaksana, merumuskan ukuran keberhasilan, menyesuaikan program tersebut dengan kegiatan internal dengan situasi eksternal, dan menetapkan anggaran yang diperlukan dalam pelaksanaanya.

Hal tersebut sesuai dengan tahapan perencanaan pendidikan karakter yang dikemukakan oleh Banghart and Trull dalam (Sa'ud, 2007:48) bahwa dalam penyusunan perencanaan pendidikan karakter diperlukan kajian terhadap beragam kebutuhan atau taksiran yang diperlukan dalam proses pengembangan atau pelayanan pembelajaran di setiap satuan pendidikan.

Kajian awal ini harus cermat, karena fungsi kajian akan memberikan masukan tentang pencapaian program sebelumnya, sumber daya apa yang tersedia, dan apa yang akan dilakukan dan bagaimana tantangan ke depan yang akan dihadapi. Perumusan tujuan perencanaan pendidikan harus berdasarkan pada visi, misi dan hasil kajian awal tentang beragam kebutuhan atau taksiran layanan pendidikan yang diperlukan.

Pada pelaksaan pendidikan karakter melalui program pembiasaan guru selaku SDM tenaga pendidik SDIT Al Kindi mengikuti SOP yang disusun oleh team leader dan yayasan baik SOP mengenai pelaksanaannya maupun persyaratan guru dalam mengajar. Persyaratan tersebut antara lain sehat jasmani dan rohani, memiliki sertifikasi keguruan atau minimal memiliki kemampuan mendidik dan memiliki jiwa sebagai pendidik.

Memiliki kemauan sikap kerja keras, disiplin, mematuhi seluruh butir kesepakatan dengan pihak sekolah dan yayasan, mengikuti pembinaan diluar sekolah, dan peryaratan utama yang sangat ditekankan adalah guru harus beragama Islam.

Guru sebagai pelaksana pendidikan karakter yang mengajar dan berhubungan langsung dengan siswa harus memberikan contoh yang baik dengan menunjukan perilaku-perilaku dan kebiasaan yang sesuai dengan nilainilai moral dan agama. Selanjutnya, guru menyusun materi, agenda dan metode mengajar yang tepat untuk dapat mengintegrasikan pendidikan karakter melalui metode pembiasaan dengan dengan kegiatan di sekolah, mata pelajaran, dan dengan kegiatan spontan yang terjadi dalam keseharian siswa.

Integrasi pendidikan karakter melalui metode pembiasaan pada kegiatan harian di sekolah dapat dilihat dari kegiatan pembiasaan yang menekankan siswa untuk berperilaku Islami dan pembiasaan menjalankan ibadah wajib maupun sunah. Pembiasaan tersebut tidak hanya pembiasaan yang bersifat fundamenatal 
yaitu menjalankan rukun Islam, namun pembiasaan pada gaya berpakaian, sikap dan pola hidup yang Islami.

Selanjutnya integrasi pendidikan karakter melalui metode pembiasaan dalam mata pelajaran dapat terlihat dari terintegrasinya pendidikan karakter dengan RPP, PROSEM, PROTA, Silabus, dan PBM, sehingga sekolah menjamin bahwa pelaksanaan pendidikan karakter tersebut terintegrasi dengan seluruh bidang studi di Sekolah SDIT Al Kindi Kota Pekanbaru.

Pendidikan karakter melalui metode pembiasaan juga terintegrasi dengan kegiatan spontan dalam kehidupan siswa. Mengenai hal ini sekolah berupaya menanamkan kebiasaan-kebiasaan baik seperti yang dicontohkan Nabi Muhammad untuk membentuk karakter siswa agar memiliki sikap, pola hidup dan kepedulian terhadap lingkungan dan sesama.

Pelaksanaan pendidikan karakter melalui metode pembiasaan yang dijalankan oleh Sekolah SDIT Al Kindi Kota Pekanbaru sesuai dengan yang dijelaskan oleh (Wiyani, 2012:56) bahwa penerapan pendidikan di sekolah dapat ditempuh dengan mengintegrasikan konten pendidikan karakter yang telah dirumuskan kedalam seluruh mata pelajaran, mengintegrasikan pendidikan karakter ke dalam kegiatan sehari-hari di sekolah, mengintegrasikan pendidikan karakter kedalam kegiatan yang diprogamkan atau direncanakan.

Pada pelaksanaan pendidikan karakter melalui metode pembiasaan telah memenuhi syarat metode pembiasaan antara lain dilakukan untuk membentuk karakter sedini mungkin, dilakukan secara terus menerus, sekolah menetapkan standar prosedur yang harus diikuti, pebiasaan disusun secara sistematis agar lambat laun dapat menjadi pembiasaan yang disertai kata hati anak sendiri.

Keberhasilan pelaksanaan pendidikan karakter melalui metode pembiasaan tidak akan tercapai tanpa kerjasama semua pihak yang terlibat. Selain ditentukan oleh peran guru keberhasilan pendidikan karakter juga memerlukan dukungan dan kerjasama dari semua pihak terutama orang tua yang bertanggungjawab atas pendidikan karakter siswa dalam keseharian di rumah.

Sehubungan dengan hal tersebut baik guru dan orang tua memiliki tanggung jawab yang sama dalam pelaksanaan pendidikan karakter siswa melalui metode pembiasaan, oleh karena itu kerjasama antara guru dan orang tua mutlak diperlukan. Kerjasama antara guru dan orang tua dapat dijalin dengan komunikasi yang baik. Sekolah berupaya menjalin komunikasi yang baik dengan orang tua dengan melakukan komunikasi secara berkala yang ditanggungjawabi oleh wali kelas.

Cara yang dilakukan oleh sekolah antara lain adalah membuat buku penghubung antara orang tua dan wali kelas untuk menyampaikan semua temuan wali kelas maupun orang tua terhadap siswa selama disekolah setiap hari. Selain itu pihak sekolah juga memiliki nomer kontak orang tua untuk berkomunikasi mengenai kegiatankegiatan siswa. Hal tersebut dilakukan untuk memantau perkembangan karakter siswa baik di sekolah maupun di rumah. Hal tersebut sesuai dengan penjelasan yang dikemukakan oleh (Wiyani, 2012:56) bahwa membangun komunikasi kerjasama antar sekolah dengan orang tua peserta didik merupakan salah satu strategi yang dapat ditempuh dalam penerapan pendidikan karakter melalui metode pembiasaan. Peran semua unsur sekolah agar terciptanya suasana yang kondusif akan memberika iklim yang 
memungkinkan terbentuknya karakter. Oleh karenanya, peran seluruh unsur sekolah menjadi elemen yang sangat mendukung terhadap tewujudnya suasana kondusif tersebut. Sehingga kerjasama antar kepala sekolah, guru BK, dan staff harus kuat dan semuanya memiliki kepedulian yang sama terhadap pelaksanaan Pendidikan karakter di sekolah.

Pada tahap evaluasi, sekolah melakukan evaluasi melalui penilaian program pembiasaan yang telah dijalankan secara secara berkala, berkesinambungan, dan menyeluruh tentang proses dan hasil pertumbuhan serta perkembangan karakter yang dicapai peserta didik.

Tujuan penilaian dilakukan untuk mengukur seberapa jauh nilainilai yang dirumuskan sebagai standar minimal yang telah dikembangkan dan ditanamkan di sekolah, serta dihayati, diamalkan, diterapkan dan dipertahankan oleh peserta didik dalam kehidupan sehari-hari.

Hal tersebut sesuai dengan yang dikemukakan oleh Kesuma dkk (2011:137) bahwa pengawasan dan evaluasi pendidikan karakter merupakan suatu proses untuk menilai kepemilikan suatu karakter oleh anak yang dilakukan secara terencana, sistematik, dan terarah pada tujuan yang jelas.

Keberhasilan pendidikan karakter melalui metode pembiasaan dapat dilihat dari perkembangan sikap siswa yang lebih baik dari sebelumnya. Selain itu, secara spesifik pihak sekolah telah menetapkan indikator-indikator keberhasilan program pembiasaan indikator tersebut antara lain kepuasan tamu, kepuasan orang tua, Laporan wali kelas dan wakasis, laporan guru bidang studi, laporan masyarakat setempat dan lonjakan penerimaan peserta didik baru. Hal tersebut sesuai dengan penjelasan yang dikemukakan oleh (Wiyani,
2012:57) bahwa Penilaian dilakukan setiap saat, baik dalam jam pelajaran maupun diluar jam pelajaran, di kelas maupun diluar kelas dengan cara pengamatan dan pencatatan.

Pendidikan karakter melalui metode pembiasaan telah memperlihatkan keberhasilannya. Hal tersebut terlihat dari sikap siswa yang sesuai dengan nilai-nilai yang diharapkan, seperti sikap siswa yang menghargai lawan bicara, baik guru, orang tua orang yang lebih tua, mengerjakan shalat 5 waktu, siswa lakilaki selalu mengikuti shalat jumat dan terbiasa shata berjamaah di masjid, mau bersedekah, mampu membaja Al-Quran dengan tartil dan sudah ada yang yang wisuda 30 juz, bagi siswa perempuan terbiasa menutup aurat ketika keluar rumah, dan siswa laki-laki terbiasa memakai peci.

Akan tetapi walaupun pendidikan karakter melalui metode pembiasaan telah mulai memperlihatkan hasil yang baik namun sekolah terus melakukan evaluasi untuk perbaikan dan meningkatkan hasil. Evaluasi tersebut dilakukan secara berkala melalui ujian tertulis, observasi wali kelas, wawancara dengan orang tua, dan masyarakat sekitar untuk mengetahui sejauh mana program pembiasaan telah dijalankan sesuai dengan tujuan yang hendak dicapai.

Penerapan pendidikan karakter melalui metode Pembiasaan di SDIT Al Kindi Kota Pekabaru ditentukan oleh kerja sama pendidik dan tim leader sekolah, kerjasama pendidik dan wali murid, kesadaran siswa, kontrol yayasan, dan pergaulan siswa di lingkungan rumahnya. Hal tersebut sesuai dengan penjelasan yang diungkapkan oleh Banghart and Trull dalam (Sa'ud, 2007:47) bahwa keberhasilan pendidikan karakter sangat ditentukan oleh, kualitas sumber daya manusianya (kepala sekolah, guru, 
komite sekolah, karyawan, dan siswa), iklim atau pola kerjasama antar unsur dalam satuan pendidikan sebagai suatu tim kerja (team work) yang handal dan kontrol atau pengawasan dan pengendalian kegiatan selama proses pelaksanaan atau implementasi program layanan pendidikan.

Pada saat ini faktor-faktor pendukung yang teridentifikasi antara lain adalah dukungan yang baik dari orang tua karena orang tua memiliki kesamaan visi dengan sekolah dalam hal peningkatan karakter anak yang Islami. Akan tetapi faktor penghambat utama yang dihadapi adalah masalah keterbatasan kuantitas sumber daya manusia dan keterbatasan anggaran. Selain itu dari sisi siswa faktor penghambat lainnya adalah faktor lingkungan sekitar salah satunya adalah teman bermain anak di luar sekolah.

Berdasarkan hasil penelitian diketahui bahwa faktor pendukung yang paling kuat adalah dukungan dari orang tua yang membuat kerjasama antara guru dan orang tua terjalin baik, sedangkan faktor pengahambat adalah kuantitas guru, keterbatasan anggaran serta faktor lingkungan sekitar. Hal tersebut merupakan masukan bagi sekolah untuk dilakukan perbaikan untuk perencanaan program pendidikan karakter melalui metode pembiasaan berikutnya yang lebih baik.

\section{Simpulan dan Saran}

Berdasarkan hasil temuan penelitian dan pembahasan, maka dapat ditarik kesimpulan sebagai berikut:

1. Tahap perencanaan pendidikan karakter melalui metode pembiasaan dilaksanakan sebelum tahun ajaran baru. SDIT Al Kindi Kota Pekanbaru adalah mengadakan rapat dinas yang dihadiri oleh para wakil kepala sekolah dan semua guru serta staf tata usaha untuk merumuskan dan menyusun program, menentukan panduan pembiasaan untuk menjadi pedoman para guru di lapangan. Pada proses perencanaan tersebut sekolah merumuskan kurikulum yang untuk diintegrasikan dengan metode pembiasaan yang disusun isi berdasarkan kandungan Al Qur'an dan Sunnah Rosulullah serta adab sehari-hari dalam Islam. Sekolah juga menetapkan standar kompetensi bagi guru yang akan melaksanakan metode pembiasaan tersebut serta anggaran untuk biaya operasional pelaksanaan. Guru selaku pelaksana pendidikan karakter melalui program pembiasaan harus harus mengikuti SOP yang disusun oleh team leader dan yayasan baik SOP mengenai pelaksanaannya maupun persyaratan guru dalam mengajar. Persyaratan utama bagi guru yang mengajar di SDIT Al Kindi Kota Pekanbaru adalah beraga Islam, guru juga wajib mengikuti pembinaan di luar sekolah untuk memperdalam pengetahuan Agama Islam dan mengikuti aturan-aturan normatif yang ditetapkan oleh sekolah agar dapat memberikan contah yang baik bagi siswa. Anggaran biaya operasional pendidikan karakter dikelola oleh yayasan dan sumber dananya di bantu oleh pihak orang tua murid dengan iuaran per tahun.

2. Pada tahap pelaksanaan, pendidikan karakter melalui metode pembiasaan di SDIT AL-Kindi telah terintegrasi dengan kegiatan sehari-hari di sekolah, terintegrasi dengan 
semua mata pelajaran dan juga terintegrasi dengan kegiatan spontan siswa sehari-hari baik di sekolah maupun di luar sekolah. SDIT AL-Kindi menyusun agenda kegiatan sehari-hari yang berisi kegiatan pembiasaan siswa menjalankan ibadah wajib maupun Sunnah, selain itu sekolah berusaha membiasakan siswa menjalankan sikap dan pola hidup Islami sesuai dengan yang dicontohkan oleh Nabi Muhammad SAW. N Pada pelaksanaannya sekolah menjalin kerjasama dengan berbagai pihak terutama orang tua agar pendidikan karakter tidak hanya berjalan di sekolah melainkan juga harus dijalankan di rumah atau di lingkungan tempat tinggal siswa sehingga pendidikan karakter melalui metode pembiasaan tersebut dapat berhasil mencapai tujuan yang ditetapkan.

3. Pada tahap evaluasi, Sekolah SDIT AL-Kindi melakukan evaluasi secara berkala melalui penilaian terhadap pola sikap siswa dan ditinjau dari indikatorindikator keberhasilan program pembiasaan indikator tersebut antara lain kepuasan tamu, kepuasan orang tua, Laporan wali kelas dan wakasis, laporan guru bidang studi, laporan masyarakat setempat dan lonjakan penerimaan peserta didik baru.

4. Faktor-faktor pendukung keberhasilan antara lain kesamaan visi dan misi sekolah dengan orang tua, serta dukungan orang tua dalam pelaksanaan pendidikan karakter. Sedangkan faktor penghambat adalah keterbatasan sumber daya manusia, keterbatasan dana sertapergaulan siswa di lingkungan luar sekolah yang sulit terkontrol.

Berdasarkan pembahasan dan kesimpulan, Peneliti mengajukan beberapa saran bagi Sekolah SDIT ALKindi antara lain:

1. Pada saat ini kegiatan programpembiasaan yang dilakukan sudah cukup baik untuk menanamkan karakter siswa yang Islami sesuai karakter yang dicontohkan oleh Nabi Muhammad SAW, akan tetapi kegiatan harian terkesan monoton, terlebih sekolah menerapkan kegiatan Full Day. Untuk menghindari kejenuhan siswa, sekolah disarankan untuk membuat kegiatan harian yang lebih variatif, misalnya diadakan kegiatan pembelajaran di luar sekolah. Selain menghindari kejenuhan siswa, kegiatan pembelajaran di luar sekolah baik untuk meningkatkan integrasi pendidikan karakter melalui metode pembiasaan dalam kegiatan spontan.

2. Sekolah disarankan untuk mempererat kerjasama dan komunikasi dengan orang tua untuk mengawasi kegiatan sehari-hari siswa di luar sekolah.

3. Melihat adanya keterbatasan SDM, sekolah disarankan untuk meningkatkan kuantitas serta kualitas SDM terutama tenaga pendidik.

\section{Daftar Pustaka}

Kesuma, Dharma. 2011. Pendidikan Karakter Kajian Teori dan Praktik di Sekolah. Bandung: Remaja RosdaKarya

Koesoema, Doni A. 2010. Pendidikan 
Karakter. Jakarta: Grasindo

Muslich, Masnuh. 2011. Pendidikan

Karakter Menjawab Tantangan

Krisis Multidimensional. Jakarta:

Bumi Aksara

Shihab, Quraish. 1994.

MembumikanAl-Qur'an. Bandung:

Mizan

Sa'ud, Udin. 2007. Pengembangan

Profesi Guru. Bandung: Alfabeta

Suardi, Edi. 2011. Pedagogik 2, Sistem dan Tujuan Pendidikan. Bandung: Angkasa

Sudjana, Nana. 2009. Penilain Hasil

Proses Belajar Mengajar. Bandung:

Remaja Rosdakarya

Wiyani, Ardy. 2012. Save Our Children

From School Bullying. Jogjakarta:

Ar-ruzz Media. 